\title{
TYPES OF POP ART AND ITS DISTRIBUTION FLOWS
}

\author{
Dilnoza Abdumalik Qizi Abdurazzakova
}

Master, Namangan State University, Uzbekistan

\section{ABSTRACT}

Current trends in modern Uzbek pop music. The rise of a new genre of music for Uzbek listeners, the "westernization" of rap, is a time when young people have no time to think about its origins. It should be noted that the combination of sound, which is far from the analysis of "rap", the content of certain unregulated methods and tones is considered "new", and a large number of blind observers.

KEYWORDS: - Variety, rap, background, melody, integrity, monitor, stage, sound.

\section{INTRODUCTION}

Variety (Spanish - takhtasupa), pop art:

1) in the broadest sense - a general expression of genres and forms of entertainment, popular art (eternal, musical, dance, spectacular, etc.);

2) in the narrow sense - a type of professional performing arts. In Russia and other countries, pop music is referred to as music hall in the UK, variety in France, café, cabaret, and show and review in the United States. Although the origins of pop art go back to folklore, it emerged as a specific (commercial) art form in the 19th century in the democratic socio-cultural environment of major European cities.

The main form of variety is a regular variety concert held in special places. It consists of small performances of several (or solo) artists (wordsmiths, singers, dancers, actors, etc.) in a completely artistic, unique way, characterized by the simplicity and brilliance of the means of expression, originality, and the direct communication of the participants with the audience.

Variety shows are sometimes based on a thematic program that combines conferences. In Europe, pop shows were first held in cafes and restaurants, and later in adapted theaters and other venues. They included masters of words, singers, dancers and dancers, as well as acrobats and magicians. Currently, genres of speech such as monologue, feuilleton, comedy, pop (national, ball, etc.) dance, couplet and pop song, many circuses (acrobatics, juggling, tricks, etc.), theatrical miniatures, puppet shows, 
CURRENT RESEARCH JOURNAL OF PEDAGOGICS 2(12): 94-97, December

2021 DOI: https://doi.org/10.37547/pedagogics-crjp-02-12-19

ISSN 2767-3278

(C)2021 Master Journals

Crossref do: 81 Google

Accepted $18^{\text {th }}$ December, 2021 \& Published 23 th December, 2021

pantomimes, etc.[1]

In Uzbekistan (as in other Eastern countries) the development of estrad was in the following ways: on the one hand, it was adapted to the requirements of the stage (for example, performances based on the performances of Tamarakhonim and M. Koriyokubov, Yusufjon's interesting Askiya traditions, etc.) or new types of scenes based on national genres (popular stage dances such as "Pakhta", "Pilla" created by M. Turgunbaeva together with Usta Olim).

On the other hand, Uzbek pop music is enriched by the adoption of foreign art forms and styles (eg, jazz, variety orchestra, music hall). From 1956, the Uzbek Variety Theater, and later the Uzbek State Variety Association (until 1996).

Currently, the Uzbeknavo Association is responsible for the development of pop art in Uzbekistan, coordination of the activities of pop groups and soloists. Variety is included in the special education system as a field of study. Since 1996, the Tashkent Variety College, the State Conservatory of Uzbekistan and other art (music) educational institutions have been operating.

Nowadays, various genres of pop music are developing. For example, the expressive nature of "rap", "broken" methods, the vague melody system is considered "new", the beginning of a new trend, as well as the fact that the main feature of its artistic aspects is consistency. the slave level is explained. This issue is also unnatural in terms of musicology - it can be adapted to indifference.

Not only national rap, but also pop, rock and other instruments are used in an awkward, or rather vague, way. It does not require volume, timbre and range from the stylist. As we have already mentioned, the melody system is formed in the intonation, which is far from the canons of musical melody, "before the melody". It is not connected with the content of the singer's body movements, leg and arm movements.

As a background, there is no synchronization between the movements of the "dancers" and the movements of the "rappers". Integritycomposition is not observed in their actions. Existing actions and rapper's performance are not subject to the same goal. Both the rapper and the dancers and dancers are limited around their particular type of movement.[2]

In the process of singing, children should approach singing with a conscious and creative feel, rather than a formal repetition of the exercise. To do this, when you recommend singing each exercise, you should not only sing it, but also explain its main purpose in detail. Then young people will be able to consciously direct their voice, and easily overcome phonetic and technical difficulties.

First and foremost, make sure that the sound is free and complete in the middle of the range. You can then move on to singing the highs of the range.

In the process of performing pop songs, the teacher must be extremely vigilant, take the necessary measures in a timely manner, noticing that the throat is constricted, the articulation is in the wrong position, and especially the sound fatigue.

During the lesson, all types of vocal exercises are performed by young people with closed lips in the "M" (closed) sound, open vocal sounds, as well as the combination of vowels and consonants "legato", "staccato", "arpedjio", intervals, gammas, singing small melodies (popevka). and appropriate skills and competencies should be developed from them.

Equipment and devices, devices, electronic board - Hitachi, LCD - monitor, electronic indicator. Video - audio equipment, audiotape, microphone, speakers. Computer and multimedia tools, 
CURRENT RESEARCH JOURNAL OF PEDAGOGICS 2(12): 94-97, December

2021 DOI: https://doi.org/10.37547/pedagogics-crjp-02-12-19

ISSN 2767-3278

(C)2021 Master Journals

Crossref doi) 81 Google

Accepted 18 ${ }^{\text {th }}$ December, 2021 \& Published 23 ${ }^{\text {th }}$ December, 2021

computer, Dell projector, DVD drive, Web camera, video eye.

Melody is the most important means of expression in music. In this case, the characteristics of this or that idea are usually more pronounced. Kuy can tell a story based on musical sounds.

A musical idea that is more or less complete, or at least develops until it has a character image, is called a musical theme, a sequence of high-low sounds (intervals). and arises from the interaction of rhythm. First of all, the direction of movement is important here. Almost any melody is wavy, meaning that it consists of a series of upward and downward movements that complement and balance each other.

In this case, much wider intervals are often replaced by narrower intervals, which is a noisy melodic phenomenon based on the formation of a jump in the opposite direction after a gentle movement in one direction, and vice versa. the opposite is complemented by gentle movements directed in the opposite direction. Sometimes the jump itself is replaced by a jump in the opposite direction.

- Have skills such as preparing for the pop scene;

- The history and stages of development of vocal and modern music;

- Ways to work with the minus and phonogram minus;

- Classical and modern stylistic directions of pop music;

- Vocal sound registers, volume and sound capabilities;

- Reading and analysis of vocal notes;

- The basic concepts of singing pedagogy;

- Classification of singing voices;

- Psychology of musical abilities;
- The structure and operation of the sound system:

- Have an idea about the performance styles of famous Uzbek and world pop singers.[3]

It is well known that the art of music is an inexhaustible source of aesthetic perception. It is a charming world that captures the human heart and soul. Man always strives for beauty, loves it and enjoys it. She also follows these rules of beauty in her daily life and uses them wisely.

The songs are connected with all aspects of the social life of the people, they are unique art that has gone through certain stages of historical development, artistically depicting life in its own images, depending on the level of human thinking.

Our people's favorite ideologically and artistically high traditional songs express the people's life, vitality, dreams, sorrows, joys and hopes for the future. There was also a powerful voice in the fight against violence, freedom and injustice. The content of the songs is expressed through the artistic pursuit of the lyrical idea of the event, that is, the attitude, emotion and mood to the events and happenings.

Singing is an ancient and widespread form of poetry, the highest form of art. The words of the song can be read in the famous work of the 11th century linguist Mahmud Kashgari "Devonu lug'ati turk". While studying the long history of traditional Uzbek folk songs, there are many scattered songs on the three roofs of the "Devonu lug'ati turk", labor, seasonal ceremonies, and the proliferation of love-themed songs, one can see that their language is a song from bros, weights, rhymes.[4]

With the help of songs collected by Mahmud Kashgari among tribes such as Chegil and Kipchak, it can be said that songs formed a part of the literary basis for the emergence and development of Uzbek written literature. 
CURRENT RESEARCH JOURNAL OF PEDAGOGICS 2(12): 94-97, December

2021 DOI: https://doi.org/10.37547/pedagogics-crjp-02-12-19

ISSN 2767-3278

(C)2021 Master Journals

\section{Crossref dof 81 Google}

Accepted $18^{\text {th }}$ December, 2021 \& Published 23 th December, 2021

It would be true to acknowledge the Devonian Quartet as examples of written literature based on folk songs. The word of the song can be found in another famous encyclopedic scholar Yusuf Khas Hajib's "Qutadgu bilig".

The word song once meant poetry, and folk poetry was called by that term, used as a generalization term. Such a broad meaning of the song is still preserved among the people. For example, folk poets, storytellers, and princes say "I sang" and "I sang" when they wanted to tell a story. But they often use the term song.

In conclusion, the song has a broad meaning in Uzbek, expressing the combination of poetry and melody. The true meaning of art is defined by the social moral norms of a person and his life at a certain time, and beauty is enjoyed by the senses. Songs, which are one of the main genres in the Uzbek folklore, reflect the life of the people, the norms of morality through a unique art. People's inner world, ideas, hopes, dreams and confidence in the future are also characterized by originality.

Works and speeches of the First President of the Republic of Uzbekistan I. Karimov on the upbringing of harmoniously developed generation, the Law of the Republic of Uzbekistan "On Education", the National Program of Personnel Training, books on the history and practice of music, lessons based on the heritage of our ancestors brochures on the rules of application and popular scientific methodological articles and Internet materials. It does not use the words educator and trainee, but it does describe their duties and responsibilities.

In order to become an educator-teacher, to cultivate the intellect of others, to enjoy enlightenment, to cultivate a true patriot, a true citizen, first of all, to meet such high requirements of a teacher, to have such great qualities. It is argued that the educator should always be an example, which is the basic principle of education.[5]
The following scientific methods are used in this dissertation:

1. Historical comparative analysis.

2. Pedagogical analysis.

3. Tables Q\&A. Test. Conversation.

4. Pedagogical experience.

This research work can be used in the process of teaching and educating students who are mastering the skills of teaching the rules of adherence to the traditions of teacher-student collectively in all spheres of art and education. Not all young people today are polite and follow the teachings of their teachers. As I mentioned above in this dissertation, if there is a collective effort in all aspects of educational institutions, the traditions will continue and the educational process will be fruitful.

\section{ReFERENCES}

1. Odilov A., Lutfullaev A. Musical instruments - "Dust". Tashkent, 2002. P.52

2. Omonullaev D. "Music programs in secondary schools". -T.: Teacher, 1992P.36

3. Nurmatov X., Norkhodjaev N., "Alphabet of Music" -T.: Teacher, 1992 - P.48

4. Solomonova E. History of Uzbek music. T.: Teacher, 1992-P.32

5. Qosimov R. Musical instruments - "Ud". Tashkent, 2002. - P.18 